M. I. Korobko, PhD, Associate Prof.

Taras Shevchenko National University of Kyiv,

60, Volodymyrska Street, Kyiv, 01033, Ukraine

\title{
INFORMATION ETHICS AS A NECESSARY ELEMENT OF THE REGULATION OF THE MODERN INFORMATION SOCIETY
}

The article is devoted to the analysis of the importance of information ethics in the active development of information and communication technologies. Active research on the issues of cyberspace has been conducted since the second half of the XXth century. These studies are becoming more intensive every year. Many scientists are interested in analysis of these issues because communication plays the fundamental role in our dynamic modern world. Modern telecommunication technologies and, first of all, the global Internet, are one of the most important factors in the development of the world community, which has a decisive influence on the social, political, economic and socio-cultural spheres. And the global pandemic Covid-19 since 2020 has brought these issues to the forefront of socio-humanitarian research. The information space of the Internet, which has already become the main infrastructure of social communication at the local and global levels, is a relatively new cultural phenomenon. It is obvious that a clear and effective system of moral regulation in this area has not yet developed. This space provides a person with unprecedented opportunities in terms of personal freedom, challenging traditional moral attitudes. Of course, this raises many ethical issues, both general and applied, related to the spread of coercive and aggressive Internet advertising, pornography, violence, intrusion, privacy, and many other aspects. Computer technologies are not neutral. They are filled with human, cultural and social values. These values can be predicted and taken into account, they can appear and evolve after many trials and errors. In our multicultural world conflicting value system can often arise. Future research needs to do as much as possible to create a broader and more promising concept of what it means to be human in the stream of transformations that exist today. The solution of certain problems in information ethics is different depending on who solves these problems. All dilemmas and problems within the framework of the considered direction of applied ethics are open, and no one can give an exact answer to the questions yet. Thus, since in the modern information society there is a direct relationship between the intensity of technological development and the growth of crises in the field of moral values and spiritual culture, information ethics already makes a serious claim to the moral regulation of human behaviour.

Key words: digitalization, etiquette, information ethics, information and communication technologies, netiquette.

М. И. Коробко, канд. филос. наук, ассист.

Киевский национальный университет имени Тараса Шевченко,

ул. Владимирская, 60, г. Киев, 01033, Украина

\section{ИНФОРМАЦИОННАЯ ЭТИКА КАК НЕОБХОДИМЫЙ ЭЛЕМЕНТ РЕГУЛЯЦИИ СОВРЕМЕННОГО ИНФОРМАЦИОННОГО ОБЩЕСТВА}

Посвящено анализу важности информационной этики в рамках активного развития информационно-коммуникационных технологий. Активные исследования проблем киберпространства ведутся со второй половины XX века, и с каждым годом они становятся все более интенсивными. Рост интереса представителей самых разных гуманитарных дисциплин к данной проблематике объясняется не столько беспрецедентной динамикой развития объекта исследований, сколько той основополагающей ролью, которую играет коммуникация в современном мире. Современные телекоммуникационные технологии, и в первую очередь глобальная компьютерная сеть интернет, являются одним из наиболее важных факторов в развитии мирового сообщества, оказывая решающее влияние на общественную, политическую, экономическую и социокультурную сферы. А глобальная пандемия COVID-19 с 2020 г. вывела эти вопросы на первый план социогуманитарных исследований. Компьютерные технологии не нейтральны - они наполнены человеческими, культурными и социальными ценностями. Эти ценности можно предвидеть и учитывать, они способны появляться и эволюционировать после многих проб и ошибок. В поликультурном мире часто могут возникать конфликтующие системы ценностей. В будущих исследованиях необходимо сделать как можно больше в создании более широкой и перспективной концепции того, что значит быть человеком в потоке преобразований, которые сегодня происходят. Решение тех или иных проблем в информационной этике различается в зависимости от того, кто решает эти проблемы. Все дилеммы и проблемы в рамках рассматриваемого направления прикладной этики носят открытый характер, и точного ответа на поставленные вопросы пока никто не может дать.

Ключевые слова: диджитализация, этикет, информационная этика, информационно-коммуникационные технологии, нетикет.

Удк 316.74

І. І. Маслікова, д-р філос. наук, доц. Київський національний університет імені Тараса Шевченка, вул. Володимирська, 60, м. Київ, 01033, Україна i.i.maslikova@gmail.com

\section{СФЕРА КУЛЬТУРИ У ПРОЦЕСАХ НАЦІОТВОРЕННЯ ТА КОНСОЛІДАЦІЇ ГРОМАДЯН: ДОСВІД КУЛЬТУРНОЇ ПОЛІТИКИ ФРАНЦІЇ ТА НІМЕЧЧИНИ}

Досліджено позитивний і негативний досвід консолідації громадян Франції та Німеччини засобами культури. Розглянуто практики збирання творів мистецтва, що вплинули на розвиток публічних музеїв і здатність відстоювати національні інтереси; практики об'єднання громадян навколо увічнених у пам'ятниках діячів культури; практики протистояння консервативних інтелектуалів та нових мистецьких кіл, що призвели до боротьби 3 інакомисленням, знищення книжок і формування ідеології нацизму; практики нацифікації системи освіти, що виявили загострення конфлікту між ідеальними чеснотами та реальною поведінкою учасників освітнього процесу та політиків, а згодом легітимували абсолютну покірність лідеру; практики комплектації бібліотечних фондів, що супроводжувалися розкраданням публічних книгозбірень та приватних колекцій. Зазначено позитивні наслідки об'єднання громадян за допомогою культурних інститутів та виявлено негативні ефекти консолідації громадян у сучасній культурній ситуації. Надано рекомендації щодо вибудовування стратегій культурної політики України.

Ключові слова: сфера культури, культурна політика, процеси націотворення, консолідація громадян, культурні інститути.

Постановка проблеми. Згуртованість, кооперація, активне громадське життя не можуть виникати без міцного ціннісного фундаменту та стійкого відчуття належності до спільного соціального простору. Такий фундамент може закладати релігія, традиції, ідеологія. I в процесах становлення нових державних утворень правителі насаджували такі базисні цінності не лише через владний примус, але й засобами культури. Не дивно, що культурна політика, яка починає оформлюватися як явище політичного життя модерної Європи у XIX ст., бере на озброєння сферу культури та за ї̈ допомогою здійснює активні процеси націотворення. У такий спосіб культурна політика постає засобом об'єднання громадян навколо спільної мови, спільної історії, спільних культурних надбань й артефактів, спільних традицій, символів, сенсів і світоглядних настанов.

3 огляду на це доволі цікавим вважаємо історичний досвід XIX-XX ст., що демонструє важливість культур- 
ної спадщини та фуункціонуючої сфери культури для консолідації суспільства навколо спільних цілей. Звернення до досвіду авторитарних режимів, монархічних держав і демократичних країн дозволяє побачити, що сфрера культури сприяє зміцненню національної держави, $\epsilon$ невід'ємною складовою націотворення та процесів самоідентифікації громадян. Проте такі позитивні процеси можуть мати свій негативний бік, дослідження якого дозволило б зважено надавати оцінки сучасним культурним процесам і суспільним явищам та фрормувати рекомендації щодо вироблення стратегії розвитку культури в сучасній Україні.

Аналіз досліджень і публікацій. Дослідження певних елементів державотворення європейських країн, зокрема й засобами культури, у своїх роботах здійснювали Х. Арендт, О. Беннетт, А. Ріделл, А. Флеголент; Г. Козлов, О. Мосякін. Аналіз негативної консолідації та маніпуляції свідомістю громадян здійснено у працях О. Валевського, О. Мороз, П. Померанцева. Соціальні й економічні ефекти діяльності у сфері культури виявляє Д. Тросбі. Звернення до зазначених досліджень дозволить зробити висновки щодо культурних процесів у сучасній Україні з урахуванням позитивного та негативного досвіду європейських країн.

Мета статті - дослідити досвід культурної політики Франції та Німеччини в аспекті націотворення для виявлення позитивних та негативних ефектів від консолідації громадян засобами культури.

Виклад основного матеріалу дослідження. Державна культурна політика є доволі молодим політичним явищем, проте ії зародки можна простежити у практиці королівської й аристократичної протекції мистецтва, традиції якої у країнах Європи поступово згасали й найдовший час проіснували в Німеччині та Франції. У XVII-XVIII ст. таке державне втручання у сфреру культури відбувалося частіше у зв'язку з необхідністю цензури, аніж ії підтримання. Власне урядова підтримка сфери культури актуалізувалася в XIX ст., коли відбувалися процеси націотворення, що супроводжувалися заснуванням національних музеїв, галерей, бібліотек, мистецьких шкіл. У першій половині XX ст. підтримка закладів культури з боку держави досягла кульмінаційної форми, коли з'явилися перші інститути суспільного телерадіомовлення, а виконавські мистецтва, які завжди фінансували із приватних джерел, почали субсидіюватися державою. Під час Другої світової війни уряд Великої Британії заснував Раду заохочення музики та мистецтва, що була покликана сприяти сценічному та виконавському мистецтву для того, щоб підтримувати моральний дух нації в темні часи [2, с. 69-70]. У повоєнні роки уряди європейських країн створювали різноманітні ради для сприяння розвитку інституційно оформленої сфери культури.

Як зауважує британський дослідник культурної політики О. Беннетт, демократичні уряди Франції та Німеччини успадкували традиції підтримки сфрери культури, а фрранцузький президент Ф. Міттеран настільки був її прихильником, що навіть страждав на комплекс Людовіка XIV (la complexe Louis Quatorzième), оскільки сприймав своє право опікуватися мистецтвом як обов'язок, зокрема в підтриманні програми Grands Travaux, у межах якої відбувалося будівництво пам'ятників культури [2, с. 69].

Одним із яскравих прикладів того, як збирання творів мистецтва може поставати частиною державної культурної політики, є заснування та функціонування музею Лувр. Як відомо, внаслідок Французької революції колекція творів мистецтва в королівській галереї була перетворена на національний музей. Його перший керівник Д. Віван-Денон прагнув перетворити публічний музей на храм мистецтва, який слугував би доказом моральнісного й інтелектуального прогресу, породженого революцією [11, с. 14].
У зіткненні феодального та капіталістичного світів культурна спадщина постала ідеологічною зброєю революціонерів. Почалися активні процеси комплектації нових фондів, зокрема з ретельністю обирали античну скульптуру, що символізувала дух республіканських свобод, народжених античним світом й успадкованих революційною Францією. Оскільки вважали, що в середньовічні часи церква та феодали придушували свободи, мистецтво Середньовіччя та Раннього Відродження не було предметом зацікавленості збирачів нових колекцій. Крім того, новостворений публічний музей постав утіленням нового розуміння справедливості та права власності, оскільки підкреслювалася інтернаціональна значущість Лувру, що зберігав конфісковані шедеври для демонстрації звичайним громадянам та іноземцям [4, с. 70-75].

Армії республіки та згодом імперії реквізували по всій Європі найцінніші твори мистецтва, зокрема Наполеон у загарбницьких війнах укладав мирні договори, включаючи до статей про контрибуцію картини та скульптури, які передавали до Лувру. За часи Наполеона музей почав активно комплектувати фонди шедеврами Північного Відродження, тим самим поставши уособленням нового порядку, що змістив акценти з гасел про свободу та братерство на політику збирання земель часів Карла Великого. Хоча після падіння Наполеона відбулася перша в історії реституція культурних цінностей, захоплених фрранцузами, та численні твори мистецтва були повернені Святому Престолу, італійським та німецьким герцогам, австрійському імператору та прусському королю, ця історія мала надзвичайний вплив на культурну політику згаданих країн. По-перше, Австрія та Пруссія зміцнили репутацію своїх держав, оскільки повернення цінностей допомагало продемонструвати турботу про приєднання землі та здатність відстоювати національні інтереси. I такі процеси супроводжувалися вибухами патріотизму серед громадян, особливо серед молоді. По-друге, Лувр завдяки його керівнику, вченому та колекціонеру Д. Віван-Денону, створив моду на живопис старих майстрів та вплинув на фрормування публічних національних музеїв по всій Європі [4, с. 76-83]

Інший трагічний досвід формування культурної політики в аспекті націотворення продемонструвала Німеччина. У першій половині XIX ст. політична еліта князівств Німеччини повною мірою усвідомила нагальність створення культурно та лінгвістично гомогенної національної держави. Хоча повстання лібералів та інтелектуалів 1848 р. було придушено, почалися активні процеси відродження національного руху, який вів боротьбу за об'єднання Німеччини засобами культури. Незважаючи на те, що після визвольних війн другої половини $\mathrm{XIX}$ ст. не з'явилося політичної свободи та національної єдності, німці активно будували пам'ятники митцям й інтелектуалам. Буржуазія охоче зводила скульптури видатних діячів культури для пропагування етичних і громадянських чеснот - порядку, слухняності, відданості, служіння. Постаті Гете та Шиллера перетворилися на взірець моралі німецької нації. Навколо зведення пам'ятників утворився цілий культ, увічнені постаті великих німців надихали на творчість журналістів, письменників, декораторів, ілюстраторів. I така культурна політика дозволила в доволі короткий термін німцям усвідомити себе "народом поетів та мислителів" [9, с. 60-63].

Не дивно, що створена після Першої світової війни об'єднана Німеччина мала свою столицю у Веймарі, що символізував не лише нову державу, але й нову культуру, яка була фундаментом Веймарської республіки. Така культура постала ареною боротьби між старою вілгельмівською елітою, представленою аристократією, буржуазією та університетськими інтелектуалами, яка зберігала традиції, та новими мистецькими колами, що відстоювали ідеали модернізму, космополітизму, демократії. 
Опір модернізму, що чинили консервативні інтелектуали на чолі із Т. Манном і письменники фрайкору, Е. Юнгер зокрема, призвів до романтизації війни як вищої духовної сили, актуалізації жорстокості, жертовності та мужності як вищих чеснот. На такому тлі почала активізуватися інтелігенція "темних поглядів", яка не лише просувала ідеї расової дискримінації, закладаючи основи расової політики майбутньої нацистської Німеччини, але й активно виконувала функції політичних експертів з питань культури та мистецтва зокрема, очолювала національні культурні інституції. I така культурна ситуація призвела до того, що були закладені підвалини для нової тоталітарної ідеології нацизму, одним із виявів якого була боротьба з інакомисленням через публічне спалювання та плюндрування книжок, хвиля яких прокотилася Німеччиною у 30-х рр. XX ст. [9, с. 65-94].

Найважливішим інструментом подальшої духовної трансформації громадян Німеччини стала освітня система, що покликана була докорінно змінити майбутні покоління німців. Коли німецькі нацисти прийшли до влади, освітня система Німеччини була найкращою у світі, і свідченням цього була кількість лауреатів Нобелівської премії. Важливим кроком у їі реформуванні стала централізація, покликана консолідувати народ у служінні ідеям нацизму. 31933 р. почалася поступова нацифікація традиційної німецької освіти на всіх рівнях, першим кроком якої було обмеження доступу до освітнього процесу як учням-євреям, так і викладачам-євреям, а згодом повне вилучення їх з освітнього та наукового простору. Як наслідок, Німеччину залишали видатні науковці, як-от А. Ейнштейн, Н. Бор, Р. Оппенгеймер. Незважаючи на високі досягнення німецької культури, нацифікація освіти не зазнавала опору з боку її учасників, варто згадати відомий кейс співпраці з нацистами М. Гайдеґґера. Нацисти створили Націонал-соціалістичну спілку вчителів, що стала важливим інструментом культурної політики у процесах переформатування фрілософських і педагогічних засад освіти та її цінностей.

Як уже зазначалося, законослухняність була тією чеснотою, яку культивували в німецькому суспільстві. У нацистській Німеччині вона виявилася вимогою не просто слідувати закону, але й ідентифікувати себе із джерелом такого закону, утіленням якого була воля фюрера [1, с. 203-206]. Воля харизматичного лідера поставала одночасно і втіленням внутрішнього бажання німців, прагненням їхнього духу, й консолідуючим громадян чинником. 3 огляду на це вищою чеснотою почали вважати не просто законослухняність, а абсолютну покірність фюреру. Цей принцип було покладено в основу оновленої системи освіти, у якій учителі фактично перетворювалися на фюрерів у класах, а самі класні кімнати були втіленням тоталітарної держави.

Для створення "нової людини" традиційна шкільна освіта була доповнена системою елітних шкіл - орденсбург і рейхсшулен, де серйозну увагу приділяли ідеологічній та фозичній підготовці майбутніх керівників держави, а також вихованню у них лідерських якостей. Проте така система виховання вступала в певне протиріччя 3 бюрократичною машиною рейха, де фрізична сила та расова чистота супроводжувалися підступністю, лестощами, безжалісністю, хитрістю та нетерпимістю. У такий спосіб оновлений процес виховання і шлях до влади були позбавлені героїчних чеснот та не могли забезпечити цілісність держави в перспективі близького та далекого майбутнього. Ідеологи нової школи та вищої освіти усвідомлювали, що єдиним консолідуючим суспільство принципом залишалася харизматична постать фюрера, а не ідеологія націонал-соціалізму [9, с. 97-121].

Незважаючи на зазначені провали в освітній політиці, нацистська Німеччина прагнула постати центром освіченої Європи. На роль культурної столиці світу
А. Гітлером було призначено місто його дитинства Лінц. За його задумом, новий Лінц мав перетворитися на "місто мистецтв" з оперою, бібліотеками, кінотеатром та музейним комплексом. До участі в програмі "Особлива місія Лінц" було долучено чиновників партійної канцелярії, архітекторів, мистецтвознавців. Десятки антикварів і секретних агентів гестапо за керівництва Г. Поссе відшукували експонати для "місії", головні шедеври якої були пов'язані з Північним Відродженням творами Дюрера, Гольбейна, Кранаха Старшого, Альтдорфера, роботами геніїв Італійського Ренесансу, фламандським та нідерландським живописом XVIIXVIII ст. [7]. Цікавим є й те, що з України були вивезені роботи Дюрера, які були єдиною цінністю, що пройшли відбір серед творів мистецтва, розграбованих на територіях колишнього Радянського Союзу.

Як і Лувр, "Особлива місія Лінц" постала ідеологічною та політичною зброєю. За задумом Гітлера, Лінц покликаний був стати не лише символом Третього рейху, але й сховищем спільних цінностей об'єднаної свастикою Європи [4, с. 90]. Державні зібрання країн, що належали до "західної цивілізації", залишилися недоторканими, основна частина фондів була сформована за рахунок грабунку "неповноцінних народів" та аристократів, шантажу "арійців", відкупу заручників-євреїв [7]. Від початку повітряного бомбардування колекцію музею з її перлиною - Гентським вівтарем було сховано в комплексі соляних шахт Альт-Аусзеє, де на глибині 1,5 км було створене підземне музейне місто. Після того, як американські військові захопили 1945 р. Альт-Аусзеє, десять років тривав процес повернення власникам трьох мільйонів творів мистецтва.

Схожа ситуація в нацистській Німеччині була із бібліотечними фондами. Упродовж Другої світової війни тисячі бібліотек було розграбовано та сотні мільйонів книжок зникли, водночас знищуючи культурну, етнічну, релігійну ідентичність цілих спільнот і навіть народів. Найцінніші колекції для ідеології Третього рейху були розподілені між Головним управлінням безпеки рейху, де вивчали ідеологічних ворогів режиму, й оперативним штабом рейхсляйтера Розенберга, який займався конфріскацією та вивезенням з окупованих територій культурних цінностей. Значних втрат зазнали українські книгозбірні. У Парижі, наприклад, серед численних бібліотек було розграбовано емігрантську бібліотеку С. Петлюри, що містила архів документів уряду України та її лідерів, а також близько 15 тис. томів різних книжок. У межах гауптарбайтгрупе Україна працювали 150 експертів, які розкрадали сотні бібліотек та колекцій, університетські, церковні цінності, ранні друковані видання з Києво-Печерської лаври. У Києві було вилучено революційний архів документів Української народної республіки, близько 50 млн книжок, нецікавих для досліджень, було просто знищено [9, с. 187, 193, 254$257,285]$. Проте наприкінці війни почалися зворотні процеси, коли трофейні бригади Радянського Союзу стали повертати пограбовані цінності. В Україну були вивезені десятки вагонів з лабораторними приладами, друкарськими верстатами, тонни наукових книжок, твори мистецтва. Проте нестача досвідчених працівників, неспроможність зрозуміти інструкції, несумісність виробничих стандартів зробили таке обладнання непридатним. Розподіл книжок між бібліотеками теж був випадковим, і часто в бібліотеки потрапляли книги, написані мовами, незрозумілими для читачів [9, с. 324-327]. Як наслідок, залишки книжкових колекцій були розсіяні в багатьох європейських містах, і дотепер працюють групи ентузіастів-бібліофілів, які прагнуть повернути втрачене нащадкам власників книгозбірень [9, с. 353-379].

Отже, здійснений історичний екскурс дозволяє побачити, що очільники країн чітко усвідомлювали важли- 
вість сорери культури для об'єднання громадян у процесах націотворення та підсилення національної держави. Різноманітні культурні блага, які зберігаються та примножуються культурними інститутами, мають соціальну значущість, що виявляється в здатності громадян відчувати національну гордість та соціальну згуртованість, усвідомлювати себе не просто членами суспільства, а й частиною самобутньої та багатої національної культури, яка може надихати співгромадян та захоплювати представників інших країн. Культурні інститути, що $\epsilon$ втіленням спільної діяльності у сфері культури, як-от національні музеї, бібліотеки, театри, є тим простором, завдяки якому створюється особливе комфортне середовище, де активуються стимули для творчості й осмислення культурних френоменів і явищ, ведуться публічні дискусії про культуру, суспільство, мистецтво; реалізуються культурні потреби, пов'язані із творенням та долученням до різноманітних культурних благ; здійснюється освітня діяльність та відбувається накопичення й зростання наукового знання; підвищуються культурні компетентності як в актуальному часі, так і в перспективі майбутнього; осмислюється належність до культурного простору та формується національна ідентичність [5, с. 263-279; 10 , с. 63-64].

Проте важливим висновком має бути й те, що далеко не завжди консолідація громадян за допомогою засобів культури є позитивним явищем. Потреба в єднанні з іншими, солідарності, кооперації може призводити до актуалізації небезпечних явищ, як-от некритичне підкорення владному авторитету; сліпе пристосування до порядків, у яких культура постає інструментом реалізації злочинних цілей; агресивне відстоювання цінностей своєї культури та гіперболізація чеснот ії̈ представників, які підносяться на тлі нівелювання досягнень інших культур та дегуманізації іï̈ представників; маніпуляція через засоби культури думкою громадян, які некритично здатні легітимізувати злочини державної влади тощо.

Зазначені негативні ефекти консолідації членів суспільства не залишилися в трагічному минулому. Нині реальною небезпекою не лише для нашої держави, але й для країн з високим ступенем демократичної культури $€$ очевидна тенденція останніх років до зростання маніпулятивності 3МІ в поширенні "постправди" та популізму. Феномен "негативної консолідації", що виникає на тлі соціально-економічних проблем, хоча й об'єднує громадян через негативне ставлення до чинних політиків, напрямів державної політики, проте стратегічно призводить до неможливості протистояти внутрішнім та зовнішнім загрозам [3, с. 3]. Культурна практика України та сусідніх країн останнім часом засвідчує, що специфічний ТВ- та кіноконтент, певні жанри художньої літератури здатні закладати фундамент для серйозної маніпуляції думкою громадян, що у своїх наслідках призводить до зміни політичних ландшафтів і навіть до руйнування політичних інститутів, розмивання національної ідентичності та знецінення високих досягнень представників власної культури. Гарний ілюстративний матеріал до зазначеної проблеми міститься в дослідженнях О. Мороз, яка аналізує українські реалії останніх десятиліть, що породили негативне явище "вірусмейкерства" [6]; П. Померанцева, який показує, як соціальні медіа та телебачення відходять від цінностей точності, неупередженості та правдивості - передумов демократії та культури дискусії - та формують картину світу, під яку громадяни, зокрема й України, підтасовують факти та стають жертвами бандитів, релігійних франатиків, політиків-популістів та агресивних держав [8].
Висновок. Дослідження позитивних і негативних ефректів реалізації культурних політик європейських країн в аспекті націотворення дозволяє ссрормулювати рекомендації експертним громадам щодо вибудовування такої стратегії культурної політики Україні, яка, поперше, була б спрямована на консолідацію громадян, по-друге, розширювала б можливості участі в культурних процесах для різних суб'єктів соціокультурної діяльності, що мають прямі й опосередковані впливи на культуру, мінімізуючи негативні впливи держави; потретє, розширювала б доступ громадян до якісної освіти, яка фрормувала б культуру критичного та креативного мислення; по-четверте, надавала би більше можливостей для міжнародної співпраці в освітніх та культурних проєктах, що ґрунтуються на демократичних цінностях свободи, прав особистості, співпраці, взаєморозуміння та взаємної поваги представників різних культур.

\section{СПИСОК ВИКОРИСТАНИХ ДЖЕРЕЛ}

1. Арендт Х. Банальность зла. Эйхман В Иерусалиме / Х. Арендт; Пер. с англ. С. Кастальского и Н. Рудницкой. - М.: Европа, 2008. $424 \mathrm{c}$.

2. Беннетт О. Культурная политика в Соединенном Королевстве: крах мотивировок и конец традиции / О. Беннетт; Пер. с англ. В. Г. Николаева // Журнал исследований социальной политики. - 2009. - T. 7, № 1. - С. 65-88.

3. Валевський О. Л. Функції культури у формуванні суспільної консолідації / О. Л. Валевський // Аналітична записка. Серія "Гуманітарний розвиток". - 2019. - № 1. - С. 1-15.

4. Козлов Г. Замах на мистецтво: арт-детектив / Г. Козлов; Пер. із poc. С. Ушкалова. - К.: ArtHuss, 2018. - 336 с.

5. Маслікова І.І І. У пошуках спільного блага: етичні колізії соціальних практик: Монографія / І. І. Маслікова. - К.: Вид. "Міленіум", 2018. $-338 \mathrm{c}$.

6. Мороз О. Нація овочів? Як інформація змінює мислення і поведінку українців / О. Мороз. - К.: Yakaboo Publishing, 2020. - 288 с.

7. Мосякин А. Ограбленная Европа. Вселенский круговорот сокровищ / А. Мосякин. - М.: Амфора, 2014. - 416 с.

8. Померанцев П. Це не пропаганда. Подорож на війну проти реальності / П. Померанцев. - К.: Yakaboo Publishing, 2020. - 288 c.

9. Ріделл А. Книжкові злодії: Про нацистські розкрадання бібліотек Європи та спроби повернути літературну спадщину; Пер. зі швед. В. Криницький / А. Ріделл. - Харків: Вид-во "Ранок": Фабула, 2020. $400 \mathrm{c}$.

10. Тросби Д. Экономика и культура / Д. Тросби; Пер. с англ. И. Кушнаревой. - М.: Изд. дом Высшей школы экономики, 2013. - 256 с.

11. Флеголент А. Париж. Лувр / А. Флаголент // Великие музеи миpa. - 2011. - № 2. - 159 c.

\section{REFERENCES}

1. Arendt, H. (2008). Eichmann in Jerusalem: A Report on the Banality of Evil . Moskow, Evropa (In Russian).

2. Bennett, O. (2009). Cultural policy in the United Kingdom: collapsing rationales and the end of a tradition. In Zhurnal issledovanij social'noj politiki, V. 7, № 1, 65-88 (In Russian).

3. Valevs'kij, O. L. (2019). Funkciï kul'turi u formuvanni suspil'noï konsolidaciï [Functions of culture in the formation of social consolidation]. Analitichna zapiska. Serija "Gumanitarnij rozvitok". № 1, 1-15.

4. Kozlov, G. (2018). Zamah na mistectvo: art-detektiv [Assault on art: art detective]. Kyiv, ArtHuss.

5. Maslikova, I. I. (2018). U poshukah spil'nogo blaga: etichni kolizi social'nih praktik: monografija [In search of the common good: ethical collision of social practices]. Kyiv, Vid. "Milenium".

6. Moroz, O. (2020). Nacija ovochiv? Jak informacija zminjue mislennja i povedinku ukraïnciv [ls a nation of vegetables? How information changes the thinking and behavior of Ukrainians]. Kyiv, Yakaboo Publishing.

7. Mosjakin, A. (2014). Ograblennaja Evropa. Vselenskij krugovorot sokrovishh [Plundered Europe. The universal cycle of treasures]. Moskow, Amfora.

8. Pomerantsev, P. (2020). Ce ne propaganda. Podorozh na vijnu proti real'nosti [This is not propaganda. Adventures in the war against reality]. Kyiv, Yakaboo Publishing.

9. Rydell, A. (2020). Knizhkovi zlodiï: Pro nacists'ki rozkradannja bibliotek Evropi ta sprobi povernuti literaturnu spadshhinu [Book thieves: on the Nazi theft of European libraries and attempts to restore literary heritage]. Kharkiv, Vid-vo Ranok: Fabula.

10. Throsby, D. (2013). Jekonomika i kul'tura [Economics and culture]. Moskow, Izd. dom Vysshej shkoly jekonomiki.

11. Flegolent, A. (2011). Parizh. Luvr [Paris. Louvre]. In Velikie muzei mira, № 2. 
I. I. Maslikova, Dr Hab., Associate Prof.

Taras Shevchenko National University of Kyiv,

60, Volodymyrska Street, Kyiv, 01033, Ukraine

\section{THE SPHERE OF CULTURE IN THE PROCESSES OF NATION-BUILDING AND THE CONSOLIDATION OF CITIZENS: THE EXPERIENCE OF THE CULTURAL POLICY IN FRANCE AND GERMANY}

The article examines the positive and negative experience of the consolidation of French and German citizens in process of nation-building by means of culture. The research deals with: practice of collecting masterpieces that influenced the development of public museums and the ability to defend national interests; the practice of consolidation of citizens around monuments of cultural figures; practices of confrontation between conservative intellectuals and modern artistic circles, which led to the fight against dissent, the destruction of books and the formation of the ideology of Nazism; practices of nazification of the education system, which revealed growing of the conflict between ideal virtues and the real behavior of participants in the educational process and politicians, and which subsequently legitimized absolute obedience to the leader; practices of collecting library collections, accompanied by theft of public libraries and private collections.

The positive consequences of the consolidation citizens with the help of cultural institutions are indicated: the institutionally formed sphere of culture allows citizens to experience national pride, to be aware of themselves as a part of an original and rich national culture, to form their national identity. Cultural institutions create a space, which creativity is encouraged, opportunity for public discussions about culture and society are provided; educational and scientific activities are carried out.

Recommendations on building a strategy for the cultural policy of Ukraine: the sphere of culture should be aimed at consolidating citizens; should expand the possibilities of various subjects of cultural activity and minimize the negative influences of the state; should expand access to quality education that fosters a culture of critical and creative thinking; should expand opportunities for international cooperation in educational and cultural projects based on the values of rights and freedom of individuals, mutual understanding and mutual respect of representatives of different cultures.

Key words: the sphere of culture, cultural policy, the processes of nation-building, consolidation of citizens, cultural institutions.

И. И. Масликова, д-р филос. наук, доц.

Киевский национальный университет имени Тараса Шевченко,

ул. Владимирская, 60, г. Киев, 01033, Украина

\section{СФЕРА КУЛЬТУРЫ В ПРОЦЕССАХ СТАНОВЛЕНИЯ НАЦИЙ И КОНСОЛИДАЦИИ ГРАЖДАН: ОПЫТ КУЛЬТУРНОЙ ПОЛИТИКИ ФРАНЦИИ И ГЕРМАНИИ}

Исследован положительный и отрицательный опыт консолидации граждан Франции и Германии в процессах становления наций средствами культуры. Рассмотрены практики сбора произведений искусства, повлиявшие на развитие публичных музеев и способность отстаивать национальные интересы; практики объединения граждан вокруг увековеченных в памятниках деятелей культуры; практики противостояния консервативных интеллектуалов и новых художественных кругов, которые привели к борьбе с инакомыслием, уничтожению книг и формированию идеологии нацизма; практики нацификации системы образования, обнаружившие обострение конфликта между идеальными добродетелями и реальным поведением участников образовательного процесса и политиков, а впоследствии легитимизовавшие абсолютную покорность лидеру; практики комплектации библиотечных фондов, сопровождавшиеся хищением публичных библиотек и частных коллекций. Указаны положительные последствия объединения граждан с помощью культурных институтов и выявлены негативные эффекты консолидации граждан в современной культурной ситуации. Даны рекомендации по выстрачванию стратегии культурной политики Украины.

Ключевые слова: сфера культуры, культурная политика, процессы становления нации, консолидация граждан, культурные институты.

Удк $008(39+130.2)$

О. Ю. Павлова, д-р філос. наук, проф. Київський національний університет імені Тараса Шевченка, вул. Володимирська, 60, м. Київ, 01033, Україна invinover19@gmail.com

\section{ПРОБЛЕМА СПІВВІДНОШЕННЯ ПОЛІВ КУЛЬТУРНОЇ ТА ВІЗУАЛЬНОї АНТРОПОЛОГІЇ В ЛОГІЦІ КРИЗИ ТЕКСТОЦЕНТРИЧНИХ МЕТОДІВ ДОСЛІДЖЕННЯ КУЛЬТУРИ}

Присвячено вивченню актуальності антропологічних питань початку XX cm. та соціокультурних умов виникнення корпусу антропологічних наук. Досліджено специфіку предмета та метода антропології загалом як науки, що зорієнтована на систематизацію емпіричного матеріалу. У цьому контексті проаналізовано логіку формування культурної/соціальної антропології та її інструментального інтересу до візуальної продукції технічних медіа. Накопичення емпіричного матеріалу в польових дослідженнях антропологів дозволяло значно розширити предметну сферу й оптику антропологічної науки та поступово вийти візуальній антропології за межі тісї інструментальної функції, що була передбачена для неї на початку. Між тим текстоцентричний розгляд етнографічного матеріалу приводив до переведення культури корінних народів у коди західної цивілізації, а отже, до їі редукції. Накопичення відеопродукції етнографією дозволило не лише зберігати зникаючу аутентичну культуру, але й напрацювати методи систематизації візуального матеріалу, усвідомити роль візуальної антропології як автономної дисципліни поля гуманітарних наук, а також виявити непрозорість дискурсоцентричних методів дослідження культури.

Ключові слова: антропологія, культурна антропологія, візуальна антропологія, текстоцентризм, текстоцентричний розгляд етнографії, дискурсоцентричні методи дослідження культури.

Постановка проблеми. А. Купер у "Міжнародній енциклопедії антропології" відносить до антропології як сфери академічного знання чотири поля: культурну (американський варіант) та/або соціальну (британський) антропологію, біологічну антропологію, доісторичну археологію та лінгвістику [9]. Вони були започатковані наприкінці XIX - на початку XX ст. в різних країнах (як свідчить відмінність походження між культурною та соціальною антропологією). Незважаючи на те, що згодом зазначені дисципліни отримали різні стратегії проблематизації та інституалізації, вони мали спільні вихідні інтенції, що досі об'єднують достатньо різні галузі знання. До таких інтенцій належать:

- В індустріальну добу великий рівень спеціалізації та диференціації видів людської діяльності та культурних практик із новою силою актуалізував кантівське запитання про те, ким власне $є$ людина взагалі. Зазначений ракурс дослідження також став вихідним у полі "фрілософської антропології" в Німеччині (М. Шелер, Г. Плеснер, А. Гелен й ін.), яка через дискурс фрілософських наук намагалася сформулювати базові френомени людського буття. 